\title{
Evaluation of Different Onion Seed Production Methods for Improving Production and Productivity of Onion in Southern Tigray
}

\author{
Harnet Abrha $^{1^{*}} \quad$ Alem Gebretsadik $^{2} \quad$ Girmay Tesfay ${ }^{3}$ \\ 1.Ethiopian Agriculture Research Council Secretariat, Addis Abeba, Ethiopia P.O.Box 8115 \\ 2.Capacity Building for Scaling up of Evidence-Based Best Practices in Agricultural Production in Ethiopia \\ (CASCAPE) project, Mekelle, Ethiopia \\ 3.Department of Natural Resources Economics and Management, Mekelle University, Ethiopia
}

\begin{abstract}
Use of quality seed is a determinant factor for improving crop yield. Onion is widely grown crop by the farmers in the Raya-valley, Ethiopia which is mainly used as cash crop. Most of the farmers in this area use seeds of unknown sources of poor quality, leading to low yield. This demands establishment of local seed system for better quality and accessibility. Aiming at curbing the problem, evaluation of the performance of different onion seed production methods on yield and yield component of onion seed was conducted in Raya Alamata Woreda,Tumuga Kebele. Three seed production methods i.e. bulb to seed method (harvested bulb planted one and half month after vernalization), sliced $\left(1 / 3^{\text {rd }}\right)$ bulb treated by ash method (bulbs planted one month after vernalization) and seed to seed method were evaluated. Significantly highest onion seed yield $\left(1246.8 \mathrm{kgha}^{-1}\right)$, number of flower stalks per plant $(10.1)$ and 1000 seed weight $(4.768 \mathrm{gm})$ were recorded from sliced bulb treated by ash method. On the contrary, significantly lower seed yield, number of flower stalks and 1000 seed weight were recorded from seed to seed method. Therefore, seed production from sliced bulb treated by ash method could be recommended for seed producer farmers around in Raya-Valley. However, further studies including other treatments like newly released onion varieties, time of planting and bulb size will be crucial for improving seed yield of onion.
\end{abstract}

Keywords: Production method, Onion seed, Sliced and Ash treatment

DOI: $10.7176 / \mathrm{JNSR} / 10-9-05$

Publication date:May $31^{\text {st }} 2020$

\section{Introduction \\ Background}

Onion (Allium cepa L.), belonging to the family Alliaceae, is considered as one of the most economically important vegetable crops is produced on large scale in Ethiopia in general and south zone of Tigray in particular. Southern Tigray is considered as one of the development corridors in Tigray region, for its potential arable land and source of irrigated water suitable for large scale and small scale commercial agriculture. Area coverage by onion production has increased from 22,769 ha in $2014 / 15$ to 29,517 ha in 2015/16 production season (CSA, 2016) while productivity of the crop has reduced from 10.1 to $8.9 \mathrm{t} / \mathrm{ha}$ (CSA, 2016). This is quite lower than the potential productivity of the crop. Poor quality seed is one of the major contributors for the low yield. Vegetable production in Ethiopia relies mainly on imported seeds, and most vegetables which are produced from imported seeds do not perform very well due to germination and adaptability problems.

For the supply of such poor quality seeds, the informal sector is playing a significant role in outreaching large number of farmers. Most of the demand for onion seed is either met by private sectors, illegal seed suppliers or imported seeds. The formal sector, Ethiopian Seed Enterprise (ESE) is not generally supplying onion seed. Limited amount is catered by public sector organizations like agricultural research centers as popularization activities (Olani and Fikre, 2010). The quality of seed supplied by the informal sector in most cases is not good enough. Most of the times, there have been problems related to germination capacity of the seeds and true to typeness. The problem is further exacerbated by the short shelf life of onion seed (one year under favorable condition). Owing to these, producers are using 6 to $8 \mathrm{~kg}$ of seeds per hectare as opposed to the recommended rates of $3.5-4 \mathrm{~kg} / \mathrm{ha}$ in order to guarantee good seedling emergence (Gebreyohannes et al., 2010). This indicates that onion producer farmers are being forced to pay additional cost for maintaining the required amount of seedlings per unit area. Therefore, different demonstrations and capacity buildings on onion seed production techniques and related activities are prerequisite for improving production and productivity of onion on the area.

To address this problem, onion seed production was attempted in middle Awash, Melkassa and Holleta areas of the country under warm dry, intermediate and cooler highlands agro-ecology, respectively. Appreciable results were observed from bulb to seed method and this result led to the expansion of onion seed production to other areas such as southern zone of Tigray region. Southern Tigray is potential for onion seed production although limited emphasis was given during the past few years. However, some promising onion seed production activities were conducted in the last three years by Alamata Agriculture Research Center in collaboration with IFAD project. 
Unavailability of high yielding and sufficient quantity of good quality vegetable seed at the right place and time is among the most important constraints that limit both production and productivity in the part of the region. Quality onion seed is a key input for improving crop production and productivity. Increasing the quality of seeds can increase the yield potential of the crop significantly. Thus, it is one of the most economical and efficient inputs to agricultural development. In southern Tigray zone, most of the demand for onion seed is either met by private sectors or imported seeds. To address this problem, Capacity Building for Scaling up of Evidence-Based Best Practices in Agricultural Production in Ethiopia CASCAPE project has conducted on-farm demonstration on evaluation of different onion seed production methods at Raya-Alamata Woreda in Tumuga Kebele on selected participant farmers.

\section{Objectives}

- The objective of this study was to demonstrate on farm seed production methods through participatory way.

\section{Materials and methods}

\subsection{Study Area Description}

Alamata district is located in the Raya valley at latitude of 1362240 and 1371780 North and 526941 and 582966 East longitude, in southern Tigray. Altitude of the district ranges from 1,178 to 2,300 meters above sea level (m.a.s.l). Seventy-five percent of the district is categorized as lowland (below 1,500 m.a.s.1), and the remaining $25 \%$ is categorized as mid-highlands (1,500 to 2,300 m.a.s.l). Rainfall is characterized as bimodal i.e. short rainy season (March to May) and long rainy season (June and September). The annual mean precipitation ranges 615 to $927 \mathrm{~mm}$, with mean maximum and minimum temperatures of $23^{\circ} \mathrm{C}$ and $14^{\circ} \mathrm{C}$, respectively. Tumuga (the demonstration site) is one of the irrigation potential Kebeles in Raya-Alamata Woerda. The Kebele is located at 1218846 north latitude and 0393586 east longitude with an altitude of 1620 meters above sea level.

\subsection{Site and Farmers Selection}

Demonstration and evaluation of onion seed production methods was conducted at Raya Alamata Woreda in Tumuga Kebele in eight CASCAPE participant farmers' fields and one youth group. Farmers and research site for onion seed production were selected based on the appropriateness of the farm for seed and bulb production and willingness of the participant farmers to involve on the demonstration.

\subsection{Experimental Design and Treatments}

A variety named Bombay Red was used as a planting material for the demonstration. A plot size of $100 \mathrm{~m}^{2}$ per farmer was used for the demonstration. Onion seed production takes two seasons, one season for bulb production and the second season for seed production. The three seed production methods evaluated and demonstrated to farmers are described below.

Bulb to seed method: This method takes 10-12 months to produce seed. The bulb was grown from February to June. Following this, typical mother bulbs were selected and stored for one to two months, and the bulbs were planted in the cooler period (end of August to October). This method has the advantage of maintaining seed quality; it allows selection of bulbs of appropriate size, uniformity, typical color, shape, and easy decaying. It also makes it free from diseases and physical damages; it helps to have several stalks per bulbs and hence gives higher seed yield. Diamonium Phosphate (DAP) fertilizer at a rate of $250 \mathrm{~kg} / \mathrm{ha}^{-1}$ (all at planting) and nitrogen source, Urea at a rate of $150 \mathrm{~kg} \mathrm{ha}^{-1}$ (in splits: half at planting and the other half a month after emergence) were applied for all plots uniformly. Weeding and other cultivation activities were applied as per recommendation.

Seed to seed method: Onion seed at a rate of $4 \mathrm{~kg} / \mathrm{ha}$ was sowed under well prepared bed and transplanted by using the recommended spacing for bulb production to the main field after 55 days (when the seedlings ready for transplanting). After the onion plants have reached maturity, they were allowed to go to seeding, and the seeds were collected. The same type and rate of fertilizers were applied like in the bulb to seed method.

Sliced bulb treated by ash method: Bulb production system was the same with bulb to seed method; the difference was that bulbs were sliced $\left(1 / 3^{\text {rd }}\right)$ and treated by ash after vernalization for one month before planting. Data collection and analysis

The data collected were seed yield, number of flower stalks per plant and thousand seed weight. Data Analysis The data were subjected to analysis of variance (ANOVA) using SAS version 9.1.3 computer software (SAS Institute Inc., 2004). List Significant Difference (LSD) was used to separate and compare treatment means at 5\% probability level of significance.

\section{Results and Discussions}

\subsection{Onion Seed Yield}

Results of onion seed yield of the three seed production methods are presented in Table 1. Sliced bulb treated by ash method yielded significantly $(p \leq 0.01)$ higher seed yield of $1246.8 \mathrm{~kg} / \mathrm{ha}$ followed by bulb to seed method $(813.5 \mathrm{~kg} / \mathrm{ha})$. 
On the other hand, significantly lower onion seed yield of $507.8 \mathrm{~kg} / \mathrm{ha}$ was recorded from seed to seed method (Table 1). The highest seed yield recorded from sliced bulb (cut off $1 / 3^{\text {rd }}$ of the upper portions of mother bulbs) and treated by ash method before planting could be due to more sprouts per bulb, early breakage of bulb dormancy and uniform flower stalk formation promoted by the sliced bulb. Jones and Mann (1963) and Brewster (1994) also reported the presence of enormous differences in average seed yields observed depending on method of seed production, genotype, locality, season and soil type. The present result was also in line with the finding of Ashenafi et al (2014) who reported that planting of ash-treated cut bulbs leads to the production of the highest onion seed yield.

\subsection{Number of Flower Stalks per Plant and 1000 Seed Weight}

The highest (10.1) and significantly different number of flower stalks per plant was recorded from sliced bulb treated by ash method followed by bulb to seed method with mean stalks of 7.45 . In the contrary, the lowest flower stalks of 3.62 were recorded from seed to seed production method (Table 1). The production of higher number of flower stalks per plant from sliced and ash-treated bulbs could be attributed to the growth of more shoot primordial in sliced/cut bulbs and due to removal of apical dominance as well as due to the contribution of the ash in protection of the bulbs against fungal pathogens and rot organisms. The present finding is supported by Rashid and Singh (2000) who reported that bulb topping should be practiced to enhance vigorous sprouting. The number of stalks per plant may vary from 1 to 20 or more depending on the variety, planting method, size of mother bulb and time of plating (MARC, 2014).

With regards to thousand seed weight (TSW), significantly higher 1000 seed weight of $4.76 \mathrm{gm}$ was recorded from sliced bulb treated by ash method followed by bulb to seed method with TSW of $3.642 \mathrm{gm}$. However, a lower TSW of $3.012 \mathrm{gm}$ was recorded from seed to seed method. The higher TSW was recorded from sliced bulb treated by ash method followed by bulb to seed method. This might be due to availability of options on selection of bulbs of good size, uniform, typical colour and free from diseases in the ash treated method. It produces good quality seed per plant; hence, gives the heaviest seed weight.

Table 1. Number of flower stalks per plant, seed yield (kg/ha) and 1000 seed weight (gm) of the Bombey-red variety tested for three different seed production methods at Tumuga farmers research site during _ production season

\begin{tabular}{|l|l|l|l|}
\hline Treatments & $\begin{array}{l}\text { Number of flower stalks } \\
\text { per plant }\end{array}$ & Seed yield $(\mathrm{kg} / \mathrm{ha})$ & $\begin{array}{l}1000 \mathrm{seed} \\
\text { weight }(\mathrm{gm})\end{array}$ \\
\hline Seed to seed method & $3.623^{\mathrm{c}}$ & $507.8^{\mathrm{c}}$ & $3.012^{\mathrm{c}}$ \\
\hline Bulb to seed method & $7.450^{\mathrm{b}}$ & $813.5^{\mathrm{b}}$ & $3.642^{\mathrm{b}}$ \\
\hline Sliced bulb treated by ash & $10.100^{\mathrm{a}}$ & $1246.8^{\mathrm{a}}$ & $4.768^{\mathrm{a}}$ \\
\hline LSD (5\%) & 0.597 & 235.3 & 0.2251 \\
\hline CV (\%) & 4.9 & 15.9 & 3.4 \\
\hline
\end{tabular}

*Values connected by the same letter across a column are not statistically different at $5 \%$ significance level.

\section{Conclusions}

Onion seed can be produced by two methods: seed to seed and bulbs to seed methods, and both methods are in use in onion seed production system. But bulb to seed method is most commonly used method of onion seed production in southern zone of Tigray in particularly and Ethiopia in general. However, some private investors in Raya-valley made improvement on bulb to seed method by slicing/cutting one third of the upper part of the bulb and treating it with ash for controlling contamination.

For validating the local knowledge, CASCAPE project has conducted on-farm demonstration of three onion seed production methods including seed to seed, bulb to seed and bulb to seed sliced bulb treated by ash methods to demonstrate farmers and extension workers. The result of this demonstration has indicated that yield and yield components of onion seed was significantly influenced by the seed production methods. The highest seed yield, flower stalks per plant and 1000 seed weight were recorded from sliced bulb treated by ash method. This method has the advantage of maintaining seed quality by increasing 1000 seed weight and considerable yield increment by increasing number of flower stalks per plant from the sliced bulb.

\section{Way Forward}

Onion seed production requires more detailed knowledge and special skill compared to other vegetable crops. Preplanting, planting, harvesting, processing, drying and storage condition are fundamental operations in onion seed production activity. Therefore, onion seed should be produced by legally recognized and well equipped seed producer farmers and other cooperatives. In addition, as onion seed production needs practical knowhow, training should be given for the farmers, who have already been organized and who started onion seed production, by extension workers and other organizations. 


\section{Reference}

Ashenafi W., Helen T. and Tibebu S. (2014).Influence of Bulb Treatment and Spacing Patterns on Yield and Quality of Onion Seed at Humbo Larena, Southern Ethiopia. Journal of Biology, Agriculture and Healthcare. 4: 2224-3208

Brewster J.L. (1994). Onions and Other Vegetable Alliums. CAB International, Wallingford, UK, 236 p.

CSA, 2016. Report on area, production of crops (private peasant holdings meher season). Agricultural sample survey 2015/2016.V.I. Addis Ababa, May 2016.

Fekadu M. and Dandena G. (2006). Review of the Status of Vegetable Crops Production and Marketing in Ethiopia. Uganda J. Agric. Sci. 12(2):26-30.

Gebreyohannes B., Abraham G., Kahsay B., and Dirk H. (2010). Commercialization of Vegetable Production in Alamata Woreda, Northern Ethiopia: Processes and Impact

Jones H. A. and MannL.K.(1963).Onions and Their Allies. London, Leonard Hill. pp 7-128

MARC (Melkasa Agriculture Research Center) (2014). Training Manual on Seed Production Techniques of Selected Vegetable (Tomato, Pepper, Onion, Cabbage and Carrot) crops. Unpublished document

MoARD (Ministry of Agriculture and Rural Development) (2009).Crop Variety Register. Crop Development Department, Issue No. 9, June 2006, Addis Abeba, Ethiopia.

Olani N. and Fikre M. (2010).Manual for Extension Agents and Seed Producers on Onion Seed Production Technique.http://coin.fao.org/coin-static/cms/media/7/13029380384160/onion_seed.pdf

Rashid M.A. and Singh D.P. ( 2000). A Manual on Vegetable Seed Production in Bangladesh: $1^{\text {sted. AVRDC- }}$ USAID-Bangladesh Project-Horticulture Research Centre, Bangeladesh Agricultural Research Institute Joydebpur, Gazipur 70, ANGLADESH, pp 117.

Tadesse Adgo. (2008). Farmers' Evaluation and Adoption of Improved Onion Production Package in Fogera District, south Gondar, Ethiopia. M.Sc. Thesis 